Олеговна Верещагина. - СПб, 2012. - 46 с. 6. Кузьмінський А. I. Наукові засади методичної підготовки майбутнього вчителя математики: [монографія]/ А. І. Кузьмінський, Н. А. Тарасенкова, І. А. Акуленко. - Черкаси : Вид. від. ЧНУ ім. Б. Хмельницького, 2009. - 320 с. 7. Макарченко М. Г. Модель контекстного обучения будущих учителей математики в процессе их методической подготовки : дисс. на соискание ученой степени д-ра пед. наук : 13.00.02 / Макарченко Михаил Геннадиевич; РГПУ им. А. И. Герцена. - Санкт-Петербург, 2009. - 402 с. 8. Малова И. Е. Теоретические аспекты непрерывной методической подготовки учителя [Электронный ресурс] / И. Е. Малова. - Режим доступа : http://www. jeducation.ru/5_2004/48.html. 9. Якиманская И. С.Предмет анализа - субъектный опыт / И. С. Якиманская, И. Ю. Рыжухина // Директор школы России. - 1999. - № 8. - С. 53-60.

Ольга Бондаренко

\title{
ФОРМУВАННЯ ФАХОВОЇ КОМПЕТЕНТНОСТІ МАЙБУТНІХ УЧИТЕЛІВ ГЕОГРАФІЇ ПІД ЧАС ВИВЧЕННЯ СУСПІЛЬНО-ГЕОГРАФІЧНИХ ДИСЦИПЛІН
}

Бондаренко О. В. Формування фахової компетентності майбутніх учителів географії під час вивчення суспільно-географічних дисциплін.

У статті автором визначено зміст фахової компетентності майбутніх учителів географії та іï структурні складники (аксіологічний, гносеологічний, праксеологічний, професійно-особистісний, оцінювально-рефлексивний). Розкрито потенційні можливості суспільно-географічних дисциплін, зокрема регіональної економічної і соціальної географії світу у формуванні досліджуваного феномену.

Ключові слова: компетенції, компетентність, фахова компетентність майбутніх учителів географії, структурні складники фахової компетентності, суспільногеографічні дисципліни.

Бондаренко О. В. Формирование профессиональной компетентности будущих учителей географии при изучении общественно-географических дисциплин.

В статье автором определены содержание профессиональной компетентности будущих учителей географии и ее структурные компоненты (аксиологический, гносеологический, праксеологический, профессионально-личностный, оценочнорефлексивный). Раскрыты потенциальные возможности общественно-географических дисциплин, в частности региональной экономической и социальной географии мира в формировании исследуемого феномена.

Ключевые слова: компетенции, компетентность, профессиональная компетентность будущих учителей географии, структурные составляющие профессиональной компетентности, общественно-географические дисциплины.

Bondarenko O. V. Formation of professional competence of future teachers of geography when studying social and geographical disciplines.

In the article the author defines the content of professional competence of future teachers of geography and its structural components (axiological, epistemological, praxeological, professional and personal, evaluative and reflexive). The potential of social and geographical disciplines in the formation of the studied phenomenon has been shown. 
Key words: competence, professional competence of future teachers of geography, structural components of professional competence, social and geographical discipline.

Виконання соціального замовлення в підготовці конкурентоспроможних педагогічних кадрів тісно пов’язане з подальшими пошуками шляхів підвищення якості освіти та рівня їх фахової компетентності. У процесі оволодіння обраною професією дуже важливо вчити студентів розв'язувати не тільки стратегічні завдання, а й тактичні, не тільки адекватно реагувати на всі зміни, які відбуваються в навколишньому світі, а й чітко уявляти шляхи свого професійного становлення. Нині, в умовах переорієнтації предметної парадигми освіти на компетентнісну, актуальним завданням географічних факультетів $\epsilon$ формування компетентного педагога, здатного до саморозвитку. Потенційні можливості у розв'язанні означеного завдання мають суспільно-географічні дисципліни загалом і курс «Регіональна економічна і соціальна географія світу», зокрема.

Аналіз наукової літератури свідчить, що окремі аспекти досліджуваної проблеми знайшли висвітлення у працях, присвячених професійній підготовці майбутніх учителів, яка завжди перебувала в центрі уваги науковців. Питання вдосконалення загальнопедагогічної підготовки студентів в умовах вищого навчального закладу розглядали О. Абдулліна, А. Алексюк, І. Зязюн, Н. Кузьміна, Н. Ничкало, М. Ярмаченко [3]. Закономірності та принципи професійного становлення особистості розкрито в працях Б. Ананьєва, Ф. Гоноболіна.

Окремі аспекти компетентнісної освіти висвітлено такими науковцями як: Н. Бібік, В. Бондар, О. Овчарук, О. Пометун, А. Хуторський та ін. Зацікавлення в плані розв’язання обраної проблеми викликають дослідження, присвячені саме формуванню фахової компетентності майбутнього вчителя географії (Г. Гордашевської, М. Криловця, В. Саюк, О. Топузова, О. Тімець, А. Шуканової).

Між тим, аналіз стану досліджуваної проблеми в педагогічній теорії та практиці доводить, що наявні суперечності між суспільними вимогами до особистості вчителя та його діяльності й фактичним рівнем фахової компетентності випускників педагогічних вишів до виконання соціально обумовлених професійних функцій; між об'єктивною потребою в навчально-методичному забезпеченні процесу формування означеної компетентності та недостатньою розробленістю навчально-методичного матеріалу для цього процесу, між «сучасними вимогами до формування географічної компетентності учнів і реальним рівнем професійної компетентності вчителя географії, освіта якого здійснювалась переважно традиційними методами за часів впровадження компетентнісного підходу до навчання» [6].

Mema cmammi: визначити зміст фахової компетентності майбутніх учителів географії та її структурні складники, а також розкрити потенційні можливості суспільно-географічних дисциплін, зокрема регіональної економічної і соціальної географії світу у формуванні досліджуваного феномену.

Аналіз наукової літератури дозволяє стверджувати, що нині відсутній єдиний підхід до визначення сутності базових понять досліджуваної проблеми, таких як «компетенція», «компетентність», «фахова компетентність», «професійна компетентність» [2]. Тому $\epsilon$ потреба, не заперечуючи визначень, даних іншими науковцями, враховуючи специфіку вчительської праці та вимоги, висунуті до особистості випускника географічного факультету педагогічного ВН3, сформулювати свою позицію.

У своєму дослідженні, будемо дотримуватися думки О. Тімець, яка розуміє фахову компетентність вчителя географії як «інтегральну особистісну якість, яка характеризує його здатність до розв’язання професійних проблем і типових професійних завдань, що виникають у 
реальних ситуаціях педагогічної діяльності, з використанням знань, умінь, навичок і нахилів, освітнього і життєвого досвіду, цінностей» [5, с. 46], сформованість якої забезпечує ефективність педагогічної діяльності.

Здійснивши аналіз наукової літератури з означеної проблеми з'ясовано, що фахова компетентність найчастіше науковцями розглядається як цілісна функціональна система, що має певну структуру, компонентний склад якої зумовлений специфікою діяльності в якій вона реалізується. Ураховуючи специфіку вчителя географії та вимоги, які висуваються до випускників географічних факультетів, уважаємо, що досліджувана компетентність має бути представлена такими складниками:

- аксіологічний (усвідомлення суспільної значущості професії вчителя географії, цілеспрямований стійкий інтерес до неї і бажання нею займатися після закінчення вишу, прагнення до самоосвіти і саморозвитку тощо);

- гносеологічний (система знань відповідно до ОКХ, ОПП);

- праксеологічний (система професійних вмінь: гностичних, конструктивнодослідницьких, організаторських, комунікативних);

- професійно-особистісний (особистісні професійно важливі якості особистості);

- оцінювально-рефлексивний (оцінка й адекватна самооцінка рівня сформованості фахової компетентності, рефлексія мети, процесу і результату педагогічної діяльності вчителя географії) [1].

Фахова компетентність майбутнніх учителів географії має поетапний характер формування та проходить у розвитку декілька рівнів: низький (інтуїтивний), середній (репродуктивний), достатній (продуктивний), високий (творчий) [1].

Потенційні можливості у формуванні фахової компетентності вчителів географії мають суспільно-географічні дисципліни (Географія світового господарства, Географія населення, Економічна і соціальна географія своєї області, Економічна і соціальна географія України, Регіональна економічна і соціальна географія світу, Основи промисловості, сільського господарства і транспорту та ін.), спрямовані на вивчення територіальної організації суспільства та його окремих частин - населення, економічної, соціальної, політичної сфер. Коротко схарактеризуємо специфічні риси означеного процесу на прикладі курсу «Регіональна економічна і соціальна географія світу» (РЕСГ).

Навчальна дисципліна «Регіональна економічна i соціальна географія світу» $€$ нормативним курсом для підготовки фахівців географічних спеціальностей, який спрямований на висвітлення закономірностей розвитку, сучасного стану й проблем РЕСГ світу; виявлення економіко-географічної специфіки основних регіонів світу й провідних держав; з'ясування взаємозв'язків соціально-економічних процесів на рівні регіонів й окремих країн; закономірностей геопрострової організації макрорегіонів світу [4].

Формування фахової компетентності під час вивчення РЕСГ відбувається на лекційних і лабораторних заняттях. Кожне лабораторне заняття у свойй структурі поєднує такі взаємопов’язані блоки:

- теоретичний, що передбачає виконання завдань, спрямованих на формування теоретичного аспекту фахової компетентності майбутніх учителів географії, розгляд та обговорення теоретичних положень теми;

- праксеологічний, завдання якого сприяють формуванню професійних умінь та навичок і оволодінню технологічним аспектом означеної компетентності, дозволяє майбутнім учителям узяти участь в активній розумовій, комунікативній, проектувальній і 
творчій діяльності;

- рефлексивний, що передбачає роботу майбутніх учителів із застосуванням свого досвіду, самооцінку власного рівня теоретичного й практичного складників компетентності у межах конкретної теми, самооцінку власних особистісних якостей, необхідних для подальшої практичної педагогічної діяльності;

- блок самоосвіти, який орієнтує на самостійне вивчення літературних джерел 3 досліджуваної теми.

Під час вивчення РЕСГ задля набуття професійно важливих знань, умінь і навичок майбутніми вчителями, важлива роль відводиться розв'язанню різноманітних проблемних завдань суспільно-географічного характеру, диспутам, діалогам, проблемним бесідам, діловим іграм, підготовці творчих проектів, що вимагає інтелектуальної напруги та прояву самостійності студентів (під час аналізу різноманітних обліково-статистичних даних, дослідження соціально-економічних особливостей макрорегіонів світу, складання схем, картосхем, типових планів, оформлення результатів пошуково-дослідницької роботи). Задля формування аксіологічного й оцінювально-рефлексивного складників означеної компетентності реалізуються різноманітні тренінгові вправи, розв’язуються проблемнопошукові завдання. Також перевага надається порівняльному аналізу теоретичних положень РЕСГ і стану її вивчення в практиці сучасної загальноосвітньої школи, що у своїй сукупності сприяє усвідомленню соціальної значущості професії вчителя географії, формуванню позитивної мотивації студентів, їх спрямованості на майбутню педагогічну діяльність. Для розвитку професійно необхідних якостей майбутніх учителів географії практикується написання студентами есе суспільно-географічного змісту, спрямованих на розкриття особливостей організації територіально-виробничих комплексів у конкретних природних і соціально-економічних умовах, основних напрямів подолання соціальних відмінностей у регіонах світу. Окрім того, на лабораторних заняттях увага зосереджується на вивченні та узагальненні передового педагогічного досвіду вчителів міських шкіл з удосконалення рівня фахової компетентності під час викладання «Соціально-економічної географії світу» у 10 класі.

Отже, вивчення регіональної економічної і соціальної географії світу має для майбутніх учителів географії не лише світоглядне значення, а й сприяє формуванню у них структурних складників фахової компетентності (аксіологічного, гносеологічного, праксеологічного, професійно-особистісного, оцінювально-рефлексивного), їх цілісної єдності, яка за спеціально реалізованих організаційно-дидактичних умов може переходити на більш високий рівень виявлення.

Перспективи подальших розвідок у межах окресленої проблеми вбачаємо у дослідженні організаційно-дидактичних умов формування фахової компетентності учителів майбутніх географії засобами використання електронних освітніх ресурсів.

\section{Література}

1. Бондаренко О. В. Формування готовності студентів природничо-географічних факультетів педагогічних університетів до краєзнавчої роботи з учнями: дис. на здобуття наук. ступеня канд. пед. наук : 13.00.04 / О. В. Бондаренко. - Кривий Ріг, 2009. - 266 с. 2. Гордашевська Г. І. Професійна компетентність майбутнього вчителя географії: змістовий аспект [Електронний ресурс] / Г. І. Гордашевська. - Режим доступу : http://www.irbis-nbuv. gov.ua/cgi-bin/ irbis_nbuv/cgiirbis_64.exe?5 (дата звернення: 17.11.2015). З. Криловець М. Г. Система методичної підготовки майбутніх учителів географії : дис. на здобуття наук. ступеня 
д-ра пед. наук : 13.00.02/ Криловець Микола Григорович. - Київ, 2009. - 482 с. 4. Регіональна економічніа і соціальна географія світу: [навчальна програма для студентів напряму підготовки 6.040104. Географія]/ уклад. В. Бурман. - Кривий Ріг: КПІ ДВНЗ «КНУ», 2012. - 20 с. 5. Тімець О. В. Формування фахової компетентності майбутнього вчителя географії у процесі професійної підготовки / О.В. Тімець / Уманський державний педагогічний університет ім. Павла Тичини. - Умань: Сочінський, 2010. - 340 с. 6. Шуканова А. А. Функціональна структура професійної компетентності вчителя географії в системі неперервної освіти [Електронний ресурс]/ А. А. Шуканова. - Режим доступу : http://undip.org.ua/upload/iblock/ d23/5_12.pdf (дата звернення: 17.11.2015).

Ганна Горшкова

\section{НАВЧАННЯ МАЙБУТНІХ ІНЖЕНЕРІВ-МЕТАЛУРГІВ МАТЕМАТИЧНОГО МОДЕЛЮВАННЯ У ПРОЦЕСІ РОЗВ'ЯЗУВАННЯ ПРОФЕСІЙНО СПРЯМОВАНИХ ЗАДАЧ}

Горшкова Г. А. Навчання майбутніх інженерів-металургів математичного моделювання у процесі розв’язування професійно спрямованих задач.

У статті розглядаються можливості застосування математичного моделювання у процесі професійної підготовки майбутніх інженерів-металургів. Підкреслено, що упровадження нових технологій у розроблення і функціонування металургійного комплексу значно підвищує вимоги в галузі фундаментальних наук до випускників вищих навчальних закладів інженерного профілю.

Ключові слова: математичне моделювання, модель, технологічний процес, майбутній інженер-металург, вища математика.

Горшкова А. А. Обучение будущих инженеров-металлургов математическому моделированию в процессе решения профессионально направленных задач.

В статье рассматривается возможность применения математического моделирования в процессе профессиональной подготовки будущих инженеров-металлургов. Подчеркнуто, что внедрение новых технологий в разработку и функционирование металлургического комплекса значительно повышает требования в области фундаментальных наук к выпускникам высших учебных заведений инженерного профиля.

Ключевые слова: математическое моделирование, модель, технологический процесс, будущий инженер-металлург, высшая математика.

Gorshkova H. A. Mathematical modeling training of future metallurgical engineers in the process of professionally oriented problems solution.

This article examines the possibility of using mathematical modeling in the process of future metallurgical engineers training. It was emphasized that the introduction of new technologies in the development and operation of the metallurgical complex significantly increases the demands in the field of basic sciences for university graduates of engineering profile.

Key words: mathematical modeling, model, process, future metallurgical engineer, higher mathematics.

Упровадження нових наукомістких технологій у процес розроблення i 